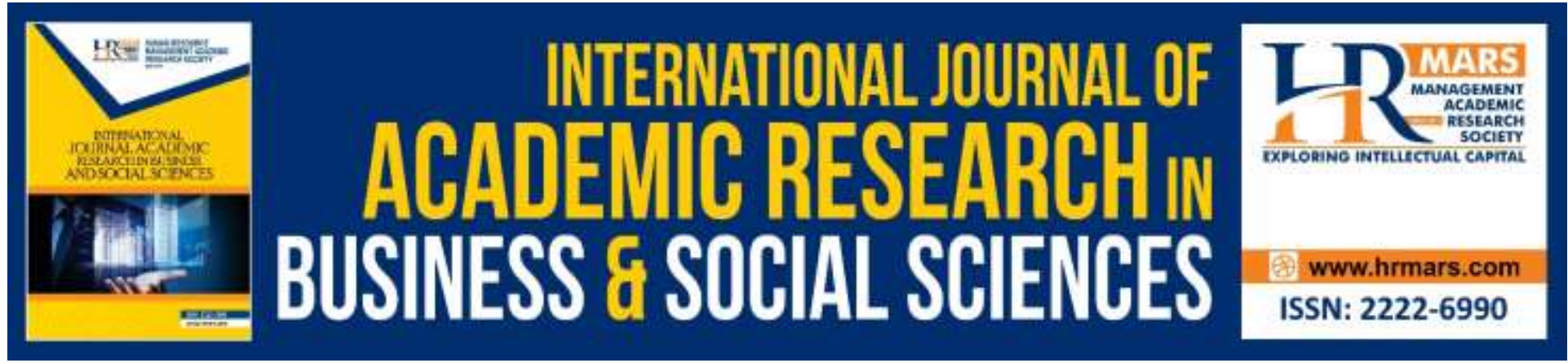

\title{
The Impact of Transformational Leadership on Employee Reactions towards Individual Work Performance: A Conceptual Paper
}

\author{
Albert Apoi and Hamrila Binti Abdul Latip
}

To Link this Article: http://dx.doi.org/10.6007/IJARBSS/v9-i8/6207

DOI: $10.6007 /$ IJARBSS/v9-i8/6207

Received: 29 May 2019, Revised: 15 June 2019, Accepted: 30 July 2019

Published Online: 23 August 2019

In-Text Citation: (Apoi, 2019)

To Cite this Article: Apoi, A. B. A. L. (2019). The Impact of Transformational Leadership on Employee Reactions towards Individual Work Performance: A Conceptual Paper. International Journal of Academic Research in Business and Social Sciences, 9(8), 47-60.

Copyright: (C) 2019 The Author(s)

Published by Human Resource Management Academic Research Society (www.hrmars.com)

This article is published under the Creative Commons Attribution (CC BY 4.0) license. Anyone may reproduce, distribute, translate and create derivative works of this article (for both commercial and non-commercial purposes), subject to full attribution to the original publication and authors. The full terms of this license may be seen at: http://creativecommons.org/licences/by/4.0/legalcode

$$
\text { Vol. 9, No. 8, 2019, Pg. } 47 \text { - } 60
$$




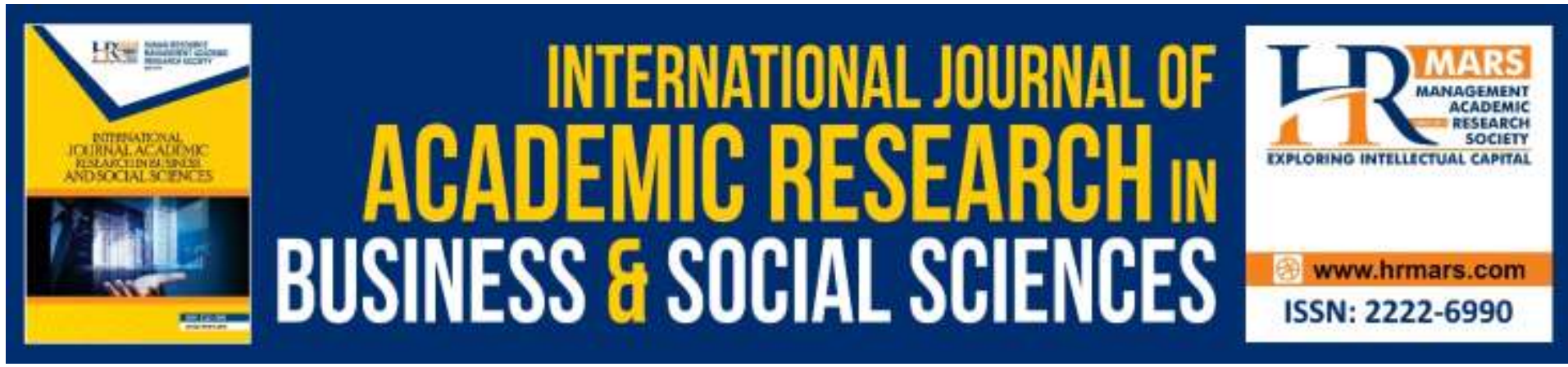

\title{
The Impact of Transformational Leadership on Employee Reactions towards Individual Work Performance: A Conceptual Paper
}

\author{
Albert Apoi and Hamrila Binti Abdul Latip \\ Faculty of Economic and Business, Universiti Malaysia Sarawak, 94300 Kota Samarahan, \\ Sarawak Malaysia. \\ Email: arbalbert@yahoo.com, alhamrila@unimas.my
}

\begin{abstract}
Interest in the impact of transformational leadership on employee reactions for decades, been the focus of research studies and variety of countries. Employee reactions are usually defined in this research specifically in terms of organizational commitment, job satisfaction and citizenship behavior. Either while such studies have focused on direct or indirect relationships between the specific factors, there is little evidence of any research, which examines the leadership effectiveness as a serially integrative relationship. This study therefore proposes a more comprehensive model of transformational leadership, which incorporates the key factors of employee reactions. The expectancy theory of motivation is used to expand and clarify the current model of leadership effectiveness. This paper claims that the reactions of employees are crucially nested in the transformational leadership individual work performance relationship. In particular, the significance of this paper is therefore to develop the serially integrative relationship model between transformational leadership, organizational commitment, organization citizenship behavior, job satisfaction and individual work performance.
\end{abstract}

Keywords: Organizational Commitment, Organizational Citizenship Behavior, Job Satisfaction, Transformational Leadership, Individual work Performance.

\section{Introduction}

Leadership is a process of social influence that can increase effectiveness of the leader and the organization (Erkutlu, 2008). Leaders naturally may exert an influence on employees; helping them to achieve specific goals within their organization. Leaders who adopt the transformational leadership approach are better able to motivate employees to perform beyond expectations (Moon, 2016). A great deal of research has examined the significant impact of transformational leadership on work outcomes such as work performance and employee reactions (Abubakr \& Hanan, 2013; Chen and Fahr, 2015). Studies of the effects of transformational leadership on employee reactions; namely organizational commitment, organizational citizenship behavior, and job satisfaction have attracted the attention of 
researchers over the last 20 years, in parallel with the shift of work motivation from a performance-centric to a person-centric perspective (Kanfer et al., 2008; Finkelstein et al., 2015). Consistent with the findings of Lau (2017), the modern working environment requires employees who possess more adaptable and creative skillsets, with team-working being a crucial part of this skillset. This skill requirement has emerged from the changing nature of the person-centric working environment; where 'big data', business analytics and a smarter mode of living are all now vitally important (George \& Haas, 2014).

Current research on employee reactions highlights how these reactions are an important tool for measuring leadership effectiveness within organizations. Understanding employee reactions through their work motivation not only promises to improve organizational productivity but also enhances the organization's human capital management (Kanfer et al., 2008). Enhancement of human capital through learning, understanding, intervening and adjusting is important for organization to identify the opportunity to evaluate and maximize the value of people (Baron \& Armstrong, 2007). Porter et al., (1973) found that employee reactions were significantly related to the performance of their organization.

Studies by Boselie et al., (2005) and Jiang et al., (2012) also supported the findings that employee reactions are related with organizational performance. In fact, numerous empirical studies have found that there is a direct positive impact of transformational leadership on employee reactions such as organizational commitment (Erkutlu, 2008; Han et al., 2016), organizational citizenship behavior (Nguni et al., 2006; Abubakr \& Hanan, 2013) and job satisfaction (Rahman et al., 2013; Choi et al., 2014). Additionally, studies have also highlighted a positive relationship within the employee reactions itself, for instance the relationship between the employees' commitment and their individual behavior (Foote \& Tang, 2008) and relationship between individual behavior and satisfaction (Feather \& Rauter, 2004). More generally, studies on the impact of transformational leadership have been extended to observe outcomes which translate into the performance of the individual and the organization (Steyrer et al., 2008; Munchiri et al., 2012).

Based on the previous studies, a positive relationship conclusively exists between leadership, employee reactions, and individual work performance (Nguni et al., 2006; Han et al., 2016). However, these studies are lacking in the perspective of the serially integrated relationship between transformational leadership, organizational commitment, organizational citizenship behavior, job satisfaction and individual work performance. Given this limitation, the present study is motivated to investigate the possibility of the existence of a serially integrated relationship.

Hence, the primary objective of this paper is to develop a serially integrative relationship model between transformational leadership, organizational commitment, organizational citizenship behavior, job satisfaction, and individual work performance. It is suggested that one of the outcomes of psychological contract between leader and employees are the behavioural consequences (Guest, 2004); whereby in the present study referred to as organizational citizenship behavior. The consequence of performing a behaviour will lead to experiencing emotions (Ajzen, 2011); for the purposes of this study, this phenomenon is referred to as employee's satisfaction.

In short, this paper will extend and refine the existing model of leadership effectiveness by assuming that employee reactions play a crucial role in leadership effectiveness model. This paper is organized as follows: in the next section a literature review 
will be presented, followed by the development of a theoretical framework and the formulation of a testable hypotheses.

\section{Literature Review}

\section{Transformational Leadership}

Transformational leaders are leaders who specifically inspire workers to 'go the extra mile' by raising workplace morale and fostering motivation; a process which ultimately brings benefits to both workers and their organization. Studies have shown that transformational leadership is generally practiced and acceptable in various industries (e.g. banking, military and hospitality) and countries with different culture settings (e.g. Malaysia, Australia and Taiwan) (Ozaralli, 2003; Brian \& Lewis, 2004; Xirasagar, 2008; Ivey \& Kline, 2010; Ling et al., 2011; Jogulu \& Ferkins, 2012; Dai et al., 2013; Abd Rahman et al., 2013; Hardy, 2014; Dg Kamisah \& Syed, 2015; Katou, 2015). On the other hand, the transactional leaders lead the team by negotiating with the followers to achieve an economic exchange relationship, where the follower will be rewarded monetarily and received a recognition in return for expected work performance (Sarros \& Santora, 2001).

It has been argued in the literature that transactional and transformational forms of leadership should be combined in order for workers and organizations to benefit to their maximum extent (Brian \& Lewis, 2004; Judge \& Piccolo, 2004; Dai et al., 2013). Evans \& Lindsay (2011) argued further that more effective leadership can be obtained via a correct blend of leadership styles practiced. Chen \& Fahr (2015) pointed out that effective leaders should also have correct leadership characteristics, exhibited in a suitable situation, while from a different perspective Erkutlu (2008) suggested that transformational leadership behaviors should be exhibited if an organization is to succeed in a rapidly changing business environment.

Following on from this body of research, this study explores the significance of the impact of transformational leadership behaviors; comparing Transactional Leadership and Laissez-Faire Leadership styles. The foundation for leadership is to observe the nature of effective leader and follower's relationship (Bass, 1985). This can be measured by measuring the level of the employee's commitment, behavior, and job satisfaction; elements which will be discussed in the next section.

\section{Employee Reactions}

Katou (2015) categorized employee reactions into four categories: motivation, organizational commitment, work engagement or satisfaction, and organizational citizenship behavior. The present study will utilize only three of these categories, namely organizational commitment, organizational citizenship behavior and satisfaction (job related), as they have been widely adopted in international leadership-effectiveness studies. These constructs are selected because they embrace a wide range of employee reactions and include psychology, behavior, and emotion.

\section{Organizational Commitment}

Organizational commitment, for example, indicates the psychological state of the employee, while organizational citizenship behavior and job satisfaction refer to the behavioral and emotional state of the employee respectively. Meyer \& Allen (1991) divided organizational commitment into three components: affective commitment (desire), continuance 
commitment (need), and normative commitment (obligation). These three aspects of commitment are a psychological state rather than being attitudinal or behavioral in nature.

\section{Organizational Citizenship Behavior}

Organizational citizenship behavior, however, refers to a form of individual behavior which is not usually recognized by any formal reward system, but which ultimately positively enhances the organization itself (Organ,1988). Citizenship behavior exhibited by employee is voluntary (Dai et al., 2013) and is typically identified as any benevolent behavior which is performed 'beyond the call of duty'; exceeding work-role requirements (Kreitner \& Kinicki, 2013).

\section{Job Satisfaction}

One of the key employee attitudes which is of interest to researchers is job satisfaction. Job satisfaction is described as an attitude rather than a behavior; reflecting how an individual feel about something (Robbins \& Coulter, 2005). According to Nelson \& Quick (2013) job satisfaction is a positive state of mind which involves emotion and which is a consequence of the employee's personal appraisal and experience of the job. Job satisfaction is considered one of the standard instruments for measuring leadership effectiveness and also reflects an organization's performance.

\section{Individual Work Performance}

Based on work and organizational psychology, individual work performance is generally defined as any behaviors or activities which affect the goals of the organization itself (Koopmans, et al., 2011). Individual work performance is, in this paper, defined in terms of behaviors or actions of employees, rather than the results of these actions. In addition, individual work performance consists of behaviors that are under the control of the individual, thus excluding behaviors that are constrained by the environment (Ratundo \& Sackett, 2002). Initially, Yukl (1989) posits leadership effectiveness as a form of consequence or outcome in general. Then, Zabid et al. (2002) suggests that this outcome can be categorized into financial, employee satisfaction with the leader and employee's commitment to the organization's goals. It may also be measured by measuring group performance, group survival, group growth, group preparedness, and collective capacity to deal with crises (Erkutlu, 2008). For the purposes of the present study, leadership effectiveness will be measured at the individual level, in terms of individual work performance, which comprises task performance, contextual performance, and counterproductive work behavior.

\section{Theoretical Framework and Hypotheses Development}

The present study adopts both expectancy theory and the new leadership model (i.e. transformational leadership) to construct a suitable theoretical framework. Expectancy theory is a process theory and focusses on the personal perceptions of the performance process (Evans \& Lindsay, 2011). There are 3 main constructs in expectancy theory: valence (how someone value the rewards), expectancy (belief that performance is from effort), and instrumentality (belief that performance is related to rewards) (Nelson \& Quick, 2013). Expectancy theory is relevant for this study as work motivation has shifted towards a more person-centric perspective (Kanfer et al., 2008), where the employee is now the focal point. Employees under the leadership of a transformational leader will tend to see themselves performing beyond what is expected of them (Bass, Leadership and Performance Beyond 
Expectations, 1985). Transformational leadership has, in fact, four interconnected elements: idealized influence (or personal appeal), inspirational motivation, intellectual stimulation, and individualized consideration (Bass, 1997).

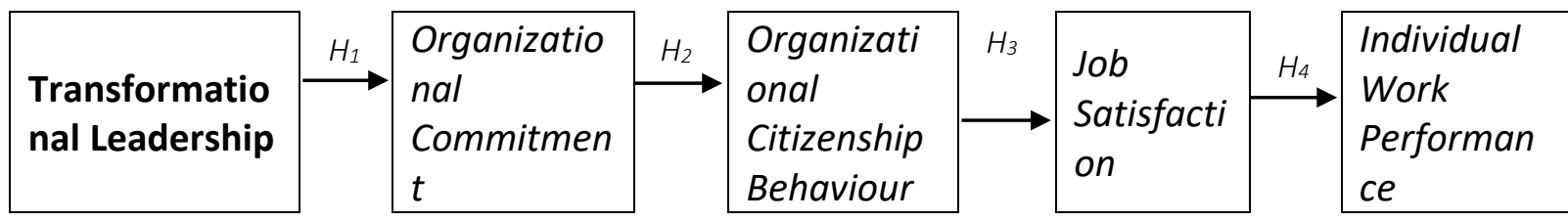

Figure 1: Theoretical Framework

There are two stages of outcomes which are the consequences of transformational leadership behavior. These are intermediate outcomes and performance outcomes. Intermediate outcomes refer to employee reactions, while performance outcome refers to the work performance at the individual level. Specifically, this study assumes that employee reactions are centrally embedded in transformational leadership and in the individual work performance relationship. The horizontal sequential path as depicted in Figure 1 is, therefore, proposed for this study. Firstly, leaders who raise employee morale and motivation through transformational leadership behavior will, of course, affect the psychological state of the employee. This is where the 'expectancy' element of expectancy theory plays a crucial role. This impact can be observed in the commitment level of employees. Secondly, committed employees will exhibit belief performance (instrumentality) which will be reflected in employee behavior.

Drawing on expectancy theory, employee perceptions of the performance process will connect performance to rewards. Thirdly, employees who value rewards (valance) and who receive them as a result of good performance will feel satisfied for being rewarded accordingly. Lastly, motivated and satisfied employees are expected to perform beyond expectations, and this is translated into their positive work performance. A proposed sequence for employee reactions may begin with organizational commitment, followed by organizational citizenship behavior, and job satisfaction. Details of this sequence are further elaborated in the hypotheses development section which follows.

Transformational Leadership and Organization Commitment

\begin{tabular}{|l|l|l|}
\hline $\begin{array}{l}\text { Transformational } \\
\text { Leadership }\end{array}$ & $\mathrm{H}_{1}$ & $\begin{array}{l}\text { Organizational } \\
\text { Commitment }\end{array}$ \\
\hline
\end{tabular}

Figure 2: Relationship between transformational leadership and organizational commitment

Transformational leadership can expand and promote employee motivation, intellect, maturity and sense of self-worth (Bass, 1997). Unlike transactional leadership, however, transformational leadership moves a step further by raising employee motivation to move beyond self-interest in order to achieve the organization's goals (Bass, 1985). Nearly two decades ago, Lok and Crawford (1999) confirmed earlier findings that leadership styles had a stronger influence on commitment. Recent studies also show how transformational 
leadership has a positive and significant impact on organizational commitment (Nguni et al., 2006; Erkutlu, 2008; Muchiri et al., 2012; Han et al., 2016). Transformational leadership primarily influences the psychological state of employees and is expressed in their level of commitment (Allen \& Meyer, 1990). The intensity of an employee's commitment will rely on the strength of the relationship of the employees with their organization. This is an ongoing process of transforming the employees by increasing their motivation and building commitment in order to win trust, admiration, and loyalty towards organizations (Yulk, 2010). Transformation by providing a vision for the employees will give them the rewards of a worker's identification with and relationship to a particular organization (p.226) (Mowday et al., 1979). Leaders who manage to motivate and uplift employee's morale and values will build trust and loyalty to the organization, benefits which are ultimately reflected in organizational commitment. The culmination of this relationship is organizational commitment. Consistent with previous findings, this paper, therefore, posits the hypothesis below to express the relationship between transformational leadership and organizational commitment:

$H_{1}$ : $\quad$ Transformational leadership is positively related to organizational commitment.

Organizational Commitment and Organizational Citizenship Behavior

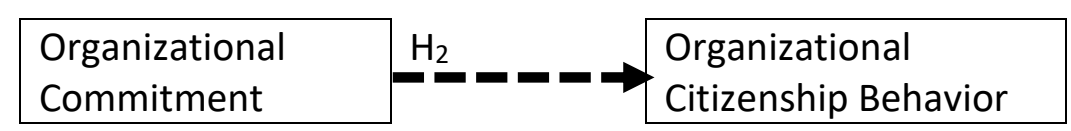

Figure 3: Relationship between organizational commitment and organizational citizenship behavior

While analysing the psychological contract, Guest (2004) explained that the outcomes of a psychological contract between leader and employees are behavioural consequences. The second relationship of employee reactions, therefore, assumes that a positive relationship of transformational leadership and organizational commitment will further integrate to organizational citizenship behavior. Organizational commitment is defined as the level of an individual's positive identification with and involvement in an organization (Mowday et al., 1979). Meyer \& Allen (1991) suggest that there are three components of organizational commitment: employee desire (affective commitment), need (continuance commitment), and obligation (normative commitment) to stay in an organization. The integrated impact from the psychological state onwards to behavioral state is due to the strong influence of the employee's identification with and involvement in the organization, awareness of the costs should they leave the organization, and feeling of obligation to continue to stay in the organization (Meyer \& Allen, 1991). A strong and positive relationship between organizational commitment and organizational citizenship behavior is also empirically supported. A recent study by Dai et al., (2013) in the hospitality industry indicates that organizational commitment has a strong and positive effect on organizational citizenship behavior. Ortiz et al., (2015) and Han et al., (2016) also support this finding in the context of private sector. Bilgin et al., (2015) specifically concluded that affective commitment is positively associated with organizational citizenship behavior. Based on above assumptions and previous studies, the hypothesis below was developed in order to understand relationship between organizational commitment and organizational citizenship behavior: 
$\mathrm{H}_{2}$ : Organizational Commitment will be positively related to Organizational Citizenship Behavior.

Organizational Citizenship Behavior and Job Satisfaction

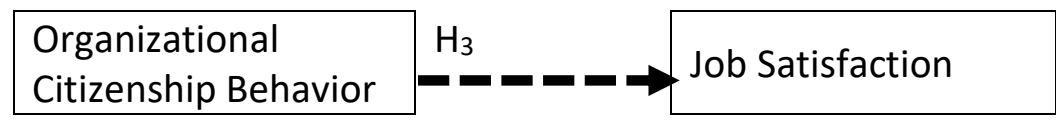

Figure 4: Relationship between organizational citizenship behavior and job satisfaction

According to Ajzen (2011) the consequence of performing any behaviour is the experiencing of emotions. Organizational citizenship behavior is, therefore, demonstrated as a result of committed employees and is typically represented by voluntary contributions (Ortiz et al., 2015). Furthermore, organizational citizenship behavior brings a positive emotional energy which comes from an overview of the quality of the job experience (Nelson \& Quick, 2013). Any voluntary action or behavior which comes from a committed employee will, naturally, bring satisfaction for that employee. The present study's assumption is drawn based on the findings of previous studies that organizational citizenship behavior (Koopmans, et al., 2011) positively affects job satisfaction for employees (Feather \& Rauter, 2004; Donavan et al., 2004; Nguni et I., 2006; Chou \& Pearson, 2012). This study adopts the view that organizational citizenship behavior affects job satisfaction, instead of the opposite. A consequence of the positive relationship discussed earlier, leadership effectiveness will affect the employee's emotional state only after affecting their psychological and behavioral state. The third relationship, therefore, assumes that there is a positive relationship between organizational citizenship behavior and job satisfaction. This forms the third hypothesis of this study, as below:

$H_{3}$ : Organizational Citizenship Behavior will be positively related to Job Satisfaction.

Job Satisfaction and Individual Work Performance

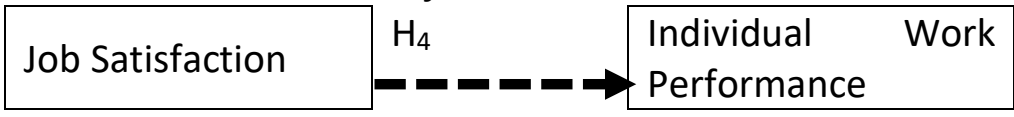

Figure 5: Relationship between job satisfaction and individual work performance

Research into the relationship between job satisfaction and work performance took place as early as the 1930s, where researchers explored the link between employees' attitudes and productivity. Various models have since been proposed and discussed such as causal effect, reciprocal relationship, correlation studies, and the most common now, which uses moderator variables (Judge \& Piccolo, 2004). Studies have also treated both job satisfaction and work performance as separate variables and have demonstrated no relationship to one another. Nevertheless, there is no concrete conclusion on the linkage between employee's attitude and performance due to the risks that this may involve. Nicholas (1993) notably argued that the linkage shows negative relationship, contrary to conclusions made by Morrison (1997). On the other hand, Bowling (2007) concluded that the relationship is largely spurious. However, research by Edwards et al., (2008), Kinicki and Fugate (2012) and Babalola (2016) on the relationship between job satisfaction and performance supported the positive relationship. Recent research by Bakotić (2016) provides 
further evidence that a relationship between both job satisfaction and performance exists in both directions. Evidence for job satisfaction causing performance was stronger compared to the reverse relationship. Hence, this study assumes that the relationship between two variables is not spurious and will focus on the causal effect whereby job satisfaction causes work performance. The study of causal effect examined the employees' and leader's relationship; otherwise known as the human relations movement in Judge and Piccolo (2004). This relationship and the causal effect of both variables are elements which this study intends to clarify. The present study, therefore, posits the hypothesis as below:

$\mathrm{H}_{4}$ : Job Satisfaction will be positively related to Individual Work Performance.

\section{Discussions}

The horizontal sequential path is proposed for this paper based on the assumption that leaders who uplift employee morale and motivation through the transformational leadership approach will have a positive psychological impact on employees. This assumption suggests that employee commitment or psychological state will be firstly impacted; resulting in increased effort. Then, employees will believe and understand that their performance demands their effort; thus, leading to a change of behavior. Stronger employee perception of the performance process will lead to the belief that performance relates to rewards; a process which can be explained by valence element in expectancy theory. Consequently, employees who value rewards and receive them as a result of good performance will feel satisfied for being rewarded accordingly. Besides, rewarding the positive behaviour brings satisfactions in employee's emotion and consequently produces favourable performance outcomes.

\section{Conclusions}

Numerous empirical studies have been examined which prove a direct impact of transformational leadership on employee reactions. However, these studies are characterized by the lack of any comprehensive view of employee reactions towards leadership because they omit any perspective of the serially integrated relationship between transformational leadership, employee reactions, and individual work performance. Thus, the present study attempts to fill this gap by developing a serially integrative relationship model between transformational leadership, organizational commitment, organizational citizenship behavior, job satisfaction and individual work performance. In short, this study is proposed to provide a more comprehensive view of leadership effectiveness by developing a serially integrative model which integrates leadership, employee reactions, and work performance. This paper may contribute to the existing literature by offering new insights into the impacts of transformational leadership on employee reactions towards individual work performance.

This field is gaining more attention in the context of present day as organizations continue to change rapidly in order to survive in a competitive and brutal business environment. Employees become increasingly important assets to an organization for their ability to generate creative and innovative ideas or solutions and work collaboratively with teammates which machine unable to replicate. Hence, putting extra attention to employee reactions now may place organization in a better business position particularly in competitiveness area in future. Therefore, decision makers and practitioners are encouraged to exhibit more transformational leadership behavior in their organization as it leaves great impact in fostering organizational commitment, organizational citizenship behavior and 
increases job satisfaction among their employees. Subsequently, individual work performance will increase.

\section{References}

Rahman, A. A., Nazir, M. M. A., Haris, M. N., Ghafar, A. A. R., \& Yushunag, T. (2013). The Influence of Leadership Style on Job Satisfaction among Nurses. Asian Social Science, 9(9), 172-178. doi:10.5539/ass.v9n9p172

Abubakr, S., \& Hanan, A. (2013). Leadership and organizational citizenship behavior (OCB) in the financial service sector: The case of the UAE. Asia-Pacific Journal of Business Administration, 5(2), 115-134. doi:http://dx.doi.org/10.1108/17574321311321603

Ajzen, I. (2011). The theory of planned behaviour: Reactions and reflections. Psychology and Health, 26(9), 1113-1127. doi:http://dx.doi.org/10.1080/08870446.2011.613995

Allen, N. J., \& Meyer, J. P. (1990). The measurement and antecendents of affective, continuance and normative commitment to the organization. Journal of Occupational Psychology, 63(1), 1-18. doi:https://doi.org/10.1111/j.2044-8325.1990.tb00506.x

Babalola, S. S. (2016). The Effect Of Leadership Style, Job Satisfaction And EmployeeSupervisor Relationship On Job Performance And Organizational Commitment. The Journal of Applied Business Research, 32(3), 935-946. doi:https://doi.org/10.19030/jabr.v32i3.9667

Bakotić, D. (2016). Relationship between job satisfaction and organisational performance. Economic Research-Ekonomska Istraživanja, 29(1), 118-130. doi:https://doi.org/10.1080/1331677X.2016.1163946

Baron, A., \& Armstrong, M. (2007). Human Capital Management: Achieving Added Value Through People. London and Philadelphia: Kogan Page.

Bass, B. M. (1985). Leadership and Performance Beyond Expectations. New York: The Free Press.

Bass, B. M. (1997). Does the Transactional - Transformational Leadership Paradigm Transcend Organizational and National Boundaries? American Psychologist, 52(2), 130-139.

Bilgin, N., Kuzey, C., Torlak, G., \& Uyar , A. (2015). An investigation of antecedents of organizational citizenship behavior in the Turkish hospitality industry: a structural equation approach. International Journal of Culture, Tourism and Hospitality Research, 9(2), 200-222. doi:https://doi.org/10.1108/IJCTHR-08-2014-0072

Borman, W., \& Motowidlo, S. (1993). Expanding the criterion domain to include elements of contextual performance. In N. Schmitt, \& W. Borman, Personnel Selection in Organizations (pp. 71-98). San Francisco, CA: Jossey Bass.

Boselie, P., Dietz, G., \& Boon, C. (2005). Commonalities and Contradictions in Research on Human Resource Management and Performance. Human Resource Management Journal, 15(3), 67-94. doi:http://dx.doi.org/10.1111/j.1748-8583.2005.tb00154.x

Bowling, N. A. (2007). Is the job satisfaction-job performance relationship spurious? A metaanalytic examination. Journal of Vocational Behavior, 71(2), 167-185. doi:https://doi.org/10.1016/j.jvb.2007.04.007

Brian, K., \& Lewis, D. (2004). Exploring leadership preferences in multicultural workgroups: As Australian case study. The Leadership \& Organization Development Journal, 25(3), 263-278. 
doi:https://doi.org/10.1108/01437730410531065

Campbell, J. (1990). Modeling the performance prediction problem in industrial and organizational psychology. In M. Dunnette, \& L. Hough, Handbook of industrial and organizational psychology (2nd ed., Vol. 1, pp. 687-732). Palo Alto, CA: Consulting Psychologists Press.

Chen, X. P., \& Fahr, J. L. (2015). Transformational and transactional leader behaviors in chinese organizations: Differential effects in the People's Republic of China and Taiwan. Advances in Global Leadership, 2, 101-126.

doi:http://dx.doi.org/10.1016/S1535-1203(01)02116-5

Choi, S. L., Wan Mardhia, M. Y., Tan, O. K., \& Low, H. H. (2014). The impact of Transformationl Leardership Style on Job Satisfaction. World Applied Sciences Journal, 29(1), 117-124. doi:10.5829/idosi.wasj.2014.29.01.1521

Chuo, S. Y., \& Pearson, J. M. (2012). Organizational citizenship behaviour in IT professionals: an expectancy theory approach. Management Research Review, 35(12), 1170-1186. doi:https://doi.org/10.1108/01409171211281282

Kamisah, D. B. A., \& Syed, A. W. (2015). The relationship between culture and leadership styles preference among Malay-Brunei, Bajau and Kadazan-Dusun community in Sabah, Malaysia. Journal of Management Development, 34(10), 1202-1210. doi:https://doi.org/10.1108/JMD-02-2015-0019

Donavan, D. T., Brown, T. J., \& Mowen, J. C. (2004). Internal Benefits of Service-Worker Customer Orientation: Job Satisfaction, Commitment, and Organizational Citizenship Behaviors. Journal of Marketing, 68, 128-146. doi:https://doi.org/10.1509/jmkg.68.1.128.24034

Edwards, B. D., Bell, S. T., Arthur Jr., W., \& Decuir, A. D. (2008). Relationships between Facets of Job Satisfaction and Task and Contextual Performance. Applied Psychology, 57(3), 441-465. doi:https://doi.org/10.1111/j.1464-

0597.2008.00328.x

Erkutlu, H. (2008). The impact of transformational leadership on organizational and leadership effectiveness: The Turkish case. Journal of Management Development, 27(7), 708 - 726. doi:10.1108/02621710810883616

Evans, J. R., \& Lindsay, W. M. (2011). Managing for Quality and Performance Excellence. Mason, Oklahoma: South-Western Cengage Learning.

Feather, N. T., \& Rauter, K. A. (2004). Organizational citizenship behaviours in relation to job status, job insecurity, organizational commitment and identification, job satisfaction and work values. Journal of Occupational and Organizational Psychology, 77, 81-94. doi:10.1348/096317904322915928

Finkelstein, L. M., Truxillo, D. M., Fraccaroli, F., \& Kanfer, R. (2015). Facing the Challenges of Multi-Age Workforce: A Use-Inspired Approach. New York: Routledge.

Foote, D. A., \& Tang, T. L. P. (2008). Job satisfaction and organizational citizenship behavior (OCB). Does team commitment make a difference in self-directed teams? Management Decision, 46(6), 933-947. doi:10.1108/00251740810882680

George, G., \& Haas, M. (2014). Big Data and Management. The Academy of Management Journal, 57(2), 321-326. Retrieved from https://doi.org/10.5465/amj.2014.4002 
Gonzalez, J. V., \& Garazo, T. G. (2006). Structural relationships between organizational service orientation, contact employee job satisfaction and citizenship behavior. International Journal of Service Industry Management, 17(1), 23-50. Retrieved from https://doi.org/10.1108/09564230610651561

Guest, D. E. (2004). The Psychology of the Employment Relationship: An Analysis Based on the Psychological Contract. International Association for Applied Psychology, 53(4), 541-555. Retrieved from https://doi.org/10.1111/j.1464-0597.2004.00187.x

Han, S. H., Seo, G., Yoon, S. W., \& Yoon, D. Y. (2016). Transformational leadership and knowledge sharing: Mediating roles of employee's empowerment, commitment, and citizenship behaviors. Journal of Workplace Learning, 28(3), 130-149. Retrieved from http://dx.doi.org/10.1108/JWL-09-2015-0066

Hardy, C. A. (2014). Transformational leadership: a quasi-experimental study. Leadership and Organization Developmment Journal, 35(1), 38-53. doi:https://doi.org/10.1108/LODJ03-2012-0033

Ivey, G., \& Kline, T. J. (2010). Transformational and active transactional leadership in Canadian military. Leadership and Organization Development Journal, 31(3), 246-262. doi:https://doi.org/10.1108/01437731011039352

Jiang, K., Lepak, D. P., Hu, J., \& Baer, J. C. (2012). How Does Human resource Management Influence Organizational Outcomes? A Meta-Analytic Investigation of Mediating Mechanisms. Academy of Management Journal, 55(6), 1264-1294. doi:http://dx.doi.org/10.5465/amj.2011.0088

Judge, T. A., \& Piccolo, R. F. (2004). Transformational and Transactional Leadership: A MetaAnalytic Test of Their Relative Validity. Journal of Applied Psychology, 89(5), 755-768. doi:10.1037/0021-9010.89.5.755

Kanfer, R., Chen, G., \& Pritchard, R. D. (2008). Work Motivation - Past, Present and Future. New York, NY: Routledge.

Katou, A. A. (2015). Transformational leadership and organisational performance: Three serially mediating mechanisms. Employee Reactions, 37(3), 329-353. doi:http://dx.doi.org/10.1108/ER-05-2014-0056

Kinicki, A., \& Fugate, M. (2012). Organizational Behavior (5th ed.). New York: McGraw-Hill.

Koopmans, L., Bernaards, C. M., Hildebrandt, V. H., Schaufeli, W. B., Vet, H. C., \& Beek, A. J. (2011). Conceptual Frameworks of Individual Work Performance: A Systematic Review. American College of Occupational and Environmental Medicine, 53(8), 856866. doi:10.1097/JOM.0b013e318226a763

Kreitner, R., \& Kinicki, A. (2013). Organizational behavior: tenth edition. New York, NY: McGraw-Hill Companies.

Lau, R. (2017). Expanding your skill set. BizHive Weekly, pp. 7-10.

Lok, P., \& Crawford, J. (1999). The relationship between commitment and organizational culture, subculture, leadership style and job satisfaction in organizational change and development. Leadership and Organization Development Journal, 20(7), 365-374. doi:https://doi.org/10.1108/01437739910302524

McShane, S. L., \& Glinow, M. A. (2012). Organizational Behavior. New York: McGraw-Hill.

Zabid, M. R. A., Sambasivan, M., \& Juliana, J. (2002). The influence of corporate culture and organisational commitment on performance. Journal of Management Development, 22(8), 708-728. doi:https://doi.org/10.1108/02621710310487873 
Meyer, J. P., \& Allen, N. J. (1991). A three-component conceptualization of organizational commitment. Human Resource Management Review, 1(1), 61-89. doi:https://doi.org/10.1016/1053-4822(91)90011-Z

Moon, K. K. (2016). The effects of diversity and transformational leadership climate on organizational citizenship behavior in the US federal government: An organizationallevel longitudinal study. Public Performance \& Management Review, 40(2), 361-381. doi:https://doi.org/10.1080/15309576.2016.1216002

Morrison, K. A. (1997). How Franchise Job Satisfaction and Personality Affects Performance, Organizational Commitment, Franchisor Relations, and Intention to Remain. Journal of Small Business Management, 35(3), 39-67.

Mowday, R. T., Steers, R. M., \& Porter, L. W. (1979). The measurement of organizational commitment. Journal of Vocational Behavior, 14(2), 224-247. doi:https://doi.org/10.1016/0001-8791(79)90072-1

Muchiri, M. K., Cooksey, R. W., \& Walumbwa, F. O. (2012). Transformational and social processes of leadership as predictors of organisational outcomes. Leadership \& Organization Development Journal, 33(7), 662-683. doi:http://dx.doi.org/10.1108/01437731211265241

Murphy, G., Anthanasou, J., \& King, N. (2002). Job satisfaction and organizational citizenship behaviour: A study of Australian human service professionals. Journal of Managerial Psychology, 17(4), 287-297. doi:https://doi.org/10.1108/02683940210428092

Nelson, D. L., \& Quick, J. C. (2013). Organizational Behavior: Science, the Real World and You (Eight Edition ed.). South-Western: Erin Joyner.

Nguni, S., Sleegers, P., \& Denessen, E. (2006). Transformational and Transactional Leadership Effects on Teachers' Job Satisfaction, Organizational Commitment and Organizational Citizenship Behavior in Primary Schools: The Tanzanian case. School Effectiveness and School Improvement, 17(2), 145 - 177. doi:10.1080/09243450600565746

Nicholas, J. P. (1993). Affective events theory and the job satisfaction-job performance relationship. Ann Arbor, Michigan: University Microfilms International.

Organ, D. W. (1988). Organizational citizenship behavior: The good soldier syndrome. Lexington MA: Lexington Books.

Ortiz, M. Z., Rosario, E., Marquez, E., \& Gruneiro, P. C. (2015). Relationship between organizational commitments and organizational citizenship behaviour in a sample of private banking employees. International Journal of Sociology and Social Policy, 35(1/2), 91-106. doi:http://dx.doi.org/10.1108/IJSSP-02-2014-0010

Ozaralli, N. (2003). Effects of transformational leadership on empowerment and team effectiveness. Leadership and Orgabization Development Journal, 24(6), 335-344. doi:https://doi.org/10.1108/01437730310494301

Podsakoff, P. M., MacKenzie, S. B., Paine, J. B., \& Bachrach, D. G. (2000). Organizational Citizenship Behaviors: A Critical Review of the Theoritical and Empirical Literature and Suggestions for Future Research. Journal of Management, 26(3), 513-563.

Porter, L. W., Dubin, R., \& Mowday, R. T. (1973). Unit Performance, Situational Factors and Employee Attitudes in Spatially Separated Work Units. Irvine, Carlifonia: University of California.

Robbins, S. P., \& Coulter, M. (2005). Management (8th ed.). Upper Saddle River, New Jersey: Pearson Prentice Hall. 
Rotundo, M., \& Sackett, P. R. (2002). The Relative Importance of Task, Citizenship, and Counterproductive Performance to Global Ratings of Job Performance: A PolicyCapturing Approach. Journal of Applied Psychology, 66-80.

Sarros, J. C., \& Santora, J. C. (2001). The transformational-transactional leadership model in practice. Leadership and Organization Development Journal, 22(8), 383-393. doi:https://doi.org/10.1108/01437730110410107

Smith, C. A., Organ, D. W., \& Near, J. P. (1983). Organizational Citizenship Behavior: Its Nature and Antecendents. Journal of Applied Psychology, 68(4), 653-663. doi:http://dx.doi.org/10.1037/0021-9010.68.4.653

Smith, P. C., Kendall, L. J., \& Hulin, C. L. (1969). The measurement of satisfaction in work and retirement: A strategy for the study of attitudes. Chicago: Rand McNally.

Smith, P., Kendall, L., \& Hulin, C. (1969). The Measurement of Satisfaction in Work and Retirement. Chicago: Rand McNally.

Spector, P. E. (1985). Development of the Job Satisfaction Survey. American Journal of Community Psychology, 13(6), 693-694. doi:https://doi.org/10.1007/BF00929796

Star Media Group, B. (2016, August 11). The Star Online. Retrieved from A hurtful job cut: https://www.thestar.com.my/metro/views/2016/08/11/a-hurtful-job-cut/

Steyrer, J., Schiffinger, M., \& Lang, R. (2008). Organizational commitment - A missing link between leadership behavior and organizational performance? Scandinavian Journal of Management, 24, 364-374.

doi:10.1016/j.scaman.2008.04.002

Weiss, D., Dawis, R., England, G., \& Lofquist, L. (1967). Manual for the Minnesota Satisfaction Questionnaire (Vol. 22). Minnesota Studies in Vocational Rehabilition, Minneapolis: University ofMinnesota, Industrial Relations Centre.

Wittig, C. (2012). Employees' Reactions to Organizational Change. OD Practitioner, 44(2), 2328.

Xirasagar, S. (2008). Transformational, transactional and laissez-faire leadership among physician executives. Journal of Health Organization and Management, 22(6), 599613. doi:https://doi.org/10.1108/14777260810916579

Yulk, G. (2010). Leadership in Organizations (7th ed.). Upper Saddler River, New Jersey: Prentice Hall. 